\title{
Lumen
}

Selected Proceedings from the Canadian Society for Eighteenth-Century Studies

\section{Madame Du Noyer, the Abbé de Bucquoy and the Birth of a Narration}

\section{Alex Sokalski}

Volume 13, 1994

URI : https://id.erudit.org/iderudit/1012531ar

DOI : https://doi.org/10.7202/1012531ar

Aller au sommaire du numéro

Éditeur(s)

Canadian Society for Eighteenth-Century Studies / Société canadienne d'étude du dix-huitième siècle

ISSN

1209-3696 (imprimé)

1927-8284 (numérique)

Découvrir la revue

Citer cet article

Sokalski, A. (1994). Madame Du Noyer, the Abbé de Bucquoy and the Birth of a Narration. Lumen, 13, 157-167. https://doi.org/10.7202/1012531ar d'utilisation que vous pouvez consulter en ligne. 


\section{Madame Du Noyer, the Abbé de Bucquoy and the Birth of a Narration}

If the name of Anne-Marguerite Petit Du Noyer is at all familiar to most scholars of the eighteenth century it is probably because of her daughter's involvement with the young François Arouet. In the process of attempting to thwart the love affair between Olympe and the future Voltaire, Madame Du Noyer would inadvertently become the first collector of Voltaire's letters, eventually the first editor of that part of his correspondence, and earn for herself a lasting albeit restricted place in his biography.

Yet, apart from this Voltaire connection, Madame Du Noyer deserves attention. A woman of great individuality and enormous intellectual capacity, she was a rather prolific author ${ }^{1}$ and, in her day, a journalist of some note. From 1712 through 1719 she collaborated on and then served as editor of the Quintessence des nouvelles published in The Hague. Her multivolumed Lettres historiques et galantes, constantly augmented during her lifetime and republished some eleven times from 1704 until 1790, became a source book, not always acknowledged, for a variety of contemporary and later eighteenth-century authors. Richard Steele, the English journalist, practically lifted his biographical sketch of Madame de Maintenon from anecdotes concerning this lady in Du Noyer's text. ${ }^{2}$ At least one of her risqué anecdotes found its way into an English jest book, Robert Baker's Witticisms and Strokes of Humour, published after $1770 .{ }^{3}$ In late eighteenth-century France, the marquis de Sade would acknowledge making use of anecdotes from her Lettres as the basis for his lost short story on the Marchioness of Thélème, although as his editor, Gilbert Lély, asserts, the 'divin marquis' doubtlessly owed more to Du Noyer than he was ready to admit. ${ }^{4}$

As early as July 1708 in a review of the first two volumes of Du Noyer's Lettres historiques et galantes, the editor of the periodical Nouvelles de la republique des lettres, Jacques Bernard, already clearly exposes what is problematic in her text. He begins with the remark: 'La Dame qui les a composées suppose deux personnes de son Sexe, dont l'une est à Paris, \& l'autre voyage dans les Provinces Méridionales de la France.' Then he 
goes on to explain that these letters contain many 'Nouvelles publiques,' 'Nouvelles' or 'Histoires particuliéres,' often with the actual names of those 'qui y ont la meilleure part,' observing:

On n'oseroit assurer que toutes ces avantures soient vrayes; il n'y a même nulle aparence, ni que dans celles qui sont vrayes, on n'y ait ajoutés certaines circonstances, pour les rendre plus agréables: mais je puis dire que j'ai été surpris d'y lire quelques avantures assez surprenantes que je sai très-certainement être arrivées, à peu près comme on les raconte. (104)

In the mid-nineteenth century, Michel Nicolas will return to this disturbing continuity between what is fictional and what is non-fictional in $\mathrm{Du}$ Noyer's Lettres. In his brief analysis of this text, he, too, starts by describing the narrative frame of the collection, using the same verb as Bernard: 'L'auteur suppose que deux dames, dont l'une est à Paris et l'autre en province, se communiquent réciproquement les nouvelles intéressantes qui viennent à leur connaissance.' Du Noyer, he explains, employs this frame to recount, 'une foule d'événements arrivés depuis 1695 jusqu'en 1717,' adding, 'en les embellisant plus d'une fois de détails empruntés à son imagination et en les présentant sous des couleurs brillantes qu'ils n'avaient certainement pas dans la réalité.' Often the author has placed, 'à côté d'aventures plus ou moins vraies, des nouvelles qu'elle inventait elle-même ou dont elle trouvait l'idée première dans des écrits antérieurs, ou dans des traditions populaires.' Before arriving at his conclusion that the Lettres are nothing more than 'un recueil d'anecdotes plus ou moins dévéloppés,' Nicolas provides this insight into Du Noyer's approach to non-fictional as well as fictional narration: 'Dans les faits qu'elle embellit et même dans ce qui n'est que le produit de son imagination, elle sait rester fidèle jusqu'à un certain point à la vérité historique, en ne prêtant aux personnages qu'elle met en scène que des actions et des paroles en rapport avec leur caractère. ${ }^{5}$ Need I add that I agree with Bernard and Nicholas that Du Noyer's Lettres historiques et galantes are a series of narrations held together through a fictional frame and sometimes themselves pure fictions, and if not fictions then not entirely distinguishable as non-fictions.

In this paper I want to restrict myself to one such non-fictional narration, Madame Du Noyer's version of the arrest and prison escapes of the abbé de Bucquoy. It is this narration that has provided her with her greatest and her most continuing exposure even though her name may not have always been attached to it. Victor Brombert observes in his Prison romantique, that the abbé's story as narrated by Du Noyer was one of two early eighteenth-century texts that helped elaborate the legend of the Bastille as a literary corpus. ${ }^{6}$ Not only did the abbé de Bucquoy, who 
must have deemed it as fulfilling all the functions of narrative structuring, recovering of events and confirming of self, himself lift it out of the Lettres and publish it along with seven of his own works in $1719{ }^{7}$ ten years after the escape, but it would be separately edited in 1788 under at least two titles: Histoire singuliere de l'abbé de Buquoit, prisonnier de la Bastille and A Un Ami, à l'occasion du mémoire de M. Mazers de la Tude ou Histoire de l'abbé de Buquoit (Paris: chez Buisson). ${ }^{8}$ In the course of time, it was to provide material for Gérard de Nerval's Faux Saulniers, first serialized in the National in 1850, then revised and retitled Histoire de l'abbé de Bucquoy in his Illuminés (1852), as well as for part of the first letter of Angélique in his Filles du feu (1854). Later in the second half of the Nineteenth Century the narration would again be extracted from the original text and published in a deluxe small format edition as L'Histoire du sieur abbé comte de Bucquoy singulièrement son évasion du For-l'Évêque et de la Bastille (Paris: Pincebourde, 1867).

In fact, this narration can be taken as a paradigm of Madame Du Noyer's approach to the non-fictional. Presented as the retelling of a reported oral narrative - 'un de mes Amis vient d'arriver de la Haye, où il a vû votre Abbé de Buquoit, qui s'y est retiré, \& qui lui a conté toutes ses Avantures. Je m'en vais vous répéter ce qu'il m'a dit là-dessus ${ }^{\prime 9}$-, her version of the abbé de Bucquoy's adventures immediately blurs any boundary between non-fiction and fiction. It is as though she is not able to conceive of the abbé's history other than in the fictional mode. The result is a kind of 'emplotment,' an intercalated 'third person narration' within the fictional narrative of the first-person exchange of letters between the lady in Paris and her lady friend in Aix-la-Chapelle.

Integrated into the narrative fabric, the narration is at the same time set apart from it. The first installment, for example, is separated from the framing letter text by either typographical ornaments or a bar, at least this is so in the two editions I have consulted, and the story title: 'Histoire de l'abbé de Buquoit.' (The ambiguity of the word 'histoire' to characterize both fiction and historical narrative is worth recalling.) At the end of the third installment, Du Noyer appends the 'Placet' which the abbé's aunt supposedly sent to the King. This text, too, is separated from the body of the narration by bold-faced print and can be considered as the end piece of the second frame of which the first piece is the story title. The narrator's own final comments align this inclusion with the initial reported retelling:

J'ai joint la copie de ce Placet à son Histoire, parce qu'il en donne en quelque maniére la clef. Mais je dois vous dire, que ceux de qui je tiens \& l'Histoire \& le Placet tenoient l'un \& l'autre de l'Abbé de Buquoit lui-même: ainsi je ne puis être garante de rien, \& je vous donne la chose se [sic] comme on me l'a donnée. (LXXV, 112-13) 
Furthermore, Du Noyer's text is as much a text on narration as it is a text of narration. The fictional narrative fabric allows for metalepsis, the opening up of the narrative text to immediate commentary on itself by the narrator, the lady from Aix-la-Chapelle, as well as by her correspondent, the lady from Paris, and, indeed, even for a kind of metanarration; the narrating lady from Aix writes:

Je ne sai si vous ne vous ennuyez point d'entendre toûjours parler de la même chose; mais je vous avouë que je me lasse de traiter toûjours le même sujet, \& qu'il a falu un motif aussi puissant que celui de vous faire plaisir, pour m'engager à une narration aussi suivie: car j'aime la diversité en toutes choses; cependant je me suis surpassée aujourd'hui, \& jamais Curé de Village, en faisant le Panégirique du Patron de sa Paroisse, n'est entré dans un plus grand détail que celui que je viens de vous faire de la Vie de l'Abbé de Buquoit; car enfin je n'en ai pas laissé échapper la moindre circonstance. \& je l'ai suivi [i.e. l'abbé] dans tous ses différens états, même jusques à l'Atrape [i.e. la Trape]. (LXXI, 44-45)

There is also a poetics of narration and letter-writing presented through the intermediary of the narrator's Parisian friend which appears somewhat less self-conscious:

une trop longue narration sentiroit plus le Livre que la Lettre, si elle n'étoit pas interrompuë à propos. Ces petits intermédes que vous avez soin de ménager raniment l'attention de la personne qui lit, \& soulagent celle qui se donne la peine d'écrire, qu'une trop longue aplication sur un même sujet ne pourroit que fatiguer. (LXXIV, 61-62)

The real author further freely plays with certain concepts of verisimilitude and with techniques of narrative structuring. When the narrating partner of the epistolary exchange questions her correspondent's interest in the abbé's story she receives the reply: 'ce n'est donc point tout ce phanatisme de l'Abbé de Buquoit qui m'a mise dans le goût de ses Avantures, mais bien son évasion de la Bastille, dont j'ai oui parler ici, \& quej'ai d'abord traitée de fable' (LXXII, 46). The correspondent's interest in the retelling is rendered believable; at the same time, the reader's attention is immediately drawn back to the main interest of the abbé's story and the narrative situation of parts two and three is skillfully set up.

Already a 'récit à tiroirs' in Genette's sense of stories recounted by $X$ to $Y$ about Z, Madame Du Noyer's narrative is further structurally fragmented into three installments spread out over six letters, LXXI to LXXVI inclusive. This structural fragmentation gives rhythm to the story. The first of the installments recounts the abbé's early studies, his military and 
then his ecclesiastical careers. His religious fanaticism affects his health and leads to his decision to reenter the secular world and return to the army; it is at this point he is arrested at Sens because of his imprudent voicing of private opinions on despotism and the rebellion of the 'fauxsauniers'. This causal explanation immediately captures the interest of the lady in Paris; she self-consciously underlines the narrator's intention as she thanks her correspondent for the extended biographical sketch: 'je vous en suis bien obligée, \& cela n'en est que mieux, parceque connoissant par là le caractére de la personne, on peut mieux comprendre de quoi elle est capable' (LXXII, 47). The conclusion of this first installment prefigures the eventually successful escapes from the prisons of Fort-l'Evêque and the Bastille in the abbé's ingenious but unsuccessful attempts to escape from custody in Sens and while en route to Paris.

In her second installment, the lady from Aix-la-Chapelle narrates the abbé de Bucquoy's successful escape from Fort-l'Evêque. Although her friend had ended her previous letter to her expressing anticipation of a quick denouement: 'toutes les Scenes ennuyeuses sont passées, \& comme nous aprochons du dénoûement, le bel-endroit va sans doute bien-tôt venir: je l'atens avec impatience' (LXXII, 48), the narrator affirms that the end is not at all so near; not only does the abbé have to escape from Fort-l'Evêque but he has to be brought to the Bastille, '\& nous avons bien du chemin à faire avant cela' (LXXIII, 49). This still-to-be-travelled road will be filled with the account of the abbé's ingenuity in orchestrating his escape from this first prison and then of his foolishness in remaining in Paris for nine months, ostensibly in order to clear his name. When he does decide to leave the kingdom it is at the most unpropitious moment and he is arrested at la Féré as a spy. Before being finally transported to the Bastille there are two more attempts at escape, both fouled by his hostess of the moment. This second part ends with the abbé brought to the Bastille; as she concludes this installment, the lady from Aix lays bare her narrative technique and subtly reminds us of the narrative frame:

voici une nouvelle captivité qui mérite bien une autre reprise; \& il me seroit impossible d'achever toute cette Histoire d'une haleine: ainsi je croi qu'il est à propos de laisser Mr. l'Abbé dans cette prison, comme nous le laissâmes l'autre jour dans l'autre, sauf à l'en retirer de même: les Epoques seront pareilles, \& trop bien marquées pour que nous puissions les oublier. Donnons-nous donc le tems de respirer, la foire n'est pas sur le pont, \& la narration est à présent assez avancée, pour que vous puissiez bien attendre encore huit jours à satisfaire pleinement votre curiosité là-dessus. (LXXII, 59-60)

The Parisian correspondent engages in this laying-bare as well. She declares that she impatiently awaits the abbé's 'sortie de la Bastille,' for 
'il me semble que cette fin couronne l'œuvre, \& qu'elle est effectivement le chef-d'œuvre de son adresse. Mais quelque empressement que j'aye d'en venir à ce dénoûement, je ne saurois trouver mauvais que vous repreniez de tems en tems haleine' (LXXIV, 61). Although she herself proceeds to detail the gossip occupying the 'Cour' and the 'Ville,' her mind is never far from her real preoccupation as is manifest in her own anecdote of the poor fellow who claims to have found the secret of manufacturing gold. He has been taken to the Bastille, 'd'ou' - she adds - 'il ne pourra pas se tirer si aisément que notre Abbé' (LXXIV, 64).

The 'crowning' of the narration is the abbé's escape from the Bastille. But the narrating correspondent delays this finale, if only momentarily, by chiding her friend in the capital for the brevity of her letter and threatening her, jokingly, to narrate this escape as succinctly as she herself did the news from Paris:

Votre derniere Lettre est si courte qu'on voit bien, Madame, que vous vous êtes dépéchée de la finir, afin de m'obliger à me hâter de vous répondre. Vous seriez bien attrapée, si j'alois vous écrire aussi succinctement, \& vous brocher en quatre mots une Avanture que vous souhaitez sans doute qu'on vous circonstancie un peu mieux! mais ne craignez rien, je suis bonne Princesse, $\&$ je m'en vais vous servir à votre mode. (LXXV, 67-68)

The narrative of Bucquoy's glorious Bastille escape is built around the topoi of all such narratives: betrayals, thwarted efforts, deceptions, near-revelations, incarceration in underground cells, frequent changes of cells, secret communications between prisoners, ingenuity in obtaining the necessary tools and in concealing them, unforeseen accidents, disputes as to the best route for escape, etc. This third installment, by far the longest part of the entire narration, is made even longer by the inclusion, as mentioned earlier, of the 'Placet' of Bucquoy's aunt to Louis XIV which expands on certain details regarding the abbé's interrogation but basically serves as a justification of his decision to escape, or, in the words of the document, his decision to 'laisser vuide la Bastille de sa personne' (108). It is perhaps the only part of Madame Du Noyer's written narration which can be directly attributed to the abbé himself, an opinion indirectly confirmed by what the Paris correspondent says regarding it:

je vois bien plus d'aparence à croire que ce Neveu a fabriqué le Placet en question dans les Païs étrangers, où l'on peut dire des véritz impunément, \& qu'il nous en donne à garder en suposant qu'il y ait eu quelqu'un d'assez hardi dans Paris, pour lever ainsi le masque. (LXXVI, 115) 
After his successful escape from the Bastille, the lady from Aix informs her Parisian friend, the abbé de Bucquoy wandered about for two years in Germany and Switzerland. At present he is in Holland, 'où il cherche à se faufiler avec les Puissances' (LXXV, 113). Other documents inform us that he was apparently successful in doing so; he was befriended by General the Field Marshall von Schulenburg who then brought him to Hanover where he remained until his death on 19 November 1740, well into his ninetieth year. Like Casanova after him, he must have entertained and intrigued his royal hosts with the story of his glorious escapes and whetted their curiosity about himself. 'Von dem abt Bucqo habe ich nichts gehört, kene ihn gar nicht, ${ }^{10}$ writes the Princess Palatine from Marly to her foster-mother, the Princess Sophie, in Hanover on 9 May 1711, probably in reply to an enquiry from the latter. In September of the same year, in a letter from Fontainebleau, she repeats that she has never heard of him and adds: 'ich habe auch nach ihm gefragt, kein mensch kent ihn. Es muss [nicht wahr sein?], dass er in der bastillen gestocken hatt. Ich kan nicht begreiffen, wie man sich von der bastillen salviren kan' (Bodemann 2, letter 769, 284).

Meanwhile, Bucquoy must also have attempted to avail himself of his host family's ties in order to try to accomplish what his 'aunt's' 'Placet' appears not to have. In October 1711, Louis XIV's sister-in-law notes that the abbé has written her but states again that she has never heard of him nor of his uncle (Bodemann 2, letter 772, 288). By 1716, writing to another correspondent, she claims that the abbé's letters to her are too long to $\operatorname{read}^{11}$ and then that she refuses to answer them because of disparaging comments about her beloved brother-in-law: 'so spricht er doch so übel von unsserm König, welchen ich so hertzlich geliebt habe undt noch regretire' (Bodemann, letter 43, 106). Eventually the Duchess begins to characterize him as the 'närischen abbé oder comte de Bouquoy. ${ }^{\prime 2}$ When she mentions him again towards the end of November 1717, she closes her reference to him with the editorial comment: 'Naren divertiren mich nie, sie jammern mich zu sehr, kan auch kein spass drin finden, dass man sie plagt' (Holland, letter 868, 138). The next month she writes in a similar vein: 'wo hatte diesser arme teüffel $14000 \mathrm{fl}$. zusamen gesamblet? Wer einmahl narisch ist, bleibt man es all sein leben' (Holland, letter 869, 142) and in January 1718: 'Es ist leicht zu glauben, dass Ihr nicht gern eine societet mitt dem nahren haben wolt; von naren hatt man nie nichts guts' (Holland, letter 879, 161). In April of that same year, after noting once again that she has not read the letter sent her by Bucquoy, she concludes: 'Narn seindt mir unertraglich' (Holland, letter 910, 247). ${ }^{13}$

The preceding sketchy portrait hardly jibes with that offered in the first part of Madame Du Noyer's account of Bucquoy's escape where the abbé is portrayed as motivated primarily by what were to become 
traditional eighteenth-century values and sentiments: the quest for truth and revolt against arbitrary authority. It does however mesh with the sense of the person one gathers from reading the 'Placet' as well as with D'Argenson's comments on Bucquoy in a letter to Pontchartrain where he judges the abbé's life to be 'un tissu de fripponneries et de mensonges $^{\prime 14}$ as well as with Pontchartrain's own assessment of a few years later: 'c'est un homme encore plus fol que dangereux' (Ravaisson, 11, 351).

The unknown author of the 'Préliminaire biographique et bibliographique' to the Histoire du sieur abbé comte de Bucquoy of 1867 makes a point of what he calls the abbé's 'intempérance de langue.' He states that outside France, Bucquoy 'surprit par son flux de paroles, dont il tirait vanité après avoir en vain entrepris de le contenir' (viii). ${ }^{15}$ The future George I of England, it is said, would not believe that the abbé's narrative was not highly coloured by his imagination, and this presumably after having heard the abbé himself recount his glorious adventures. ${ }^{16} \mathrm{Ma}-$ dame Du Noyer, as the editor points out, remarks on Bucquoy's rapid oral delivery and on his prolixity ('parler vite et longtemps,' xvi). Her writing style, however, this editor judges 'direct et facile' (xv). He seems thus to suggest that the reason Bucquoy chose to republish her narration in his 1719 Evenement des plus rares was because he was himself aware that his unrestrained language, his personal image of a loud-mouthed fool, would detract from his story's impact. He must have realized that his story would generate greater interest if well written. Even if it is formulated negatively through her fictive Parisian correspondent, Madame Du Noyer herself consciously recognized that she had brought at least this to the abbé's story: 'Comme vous n'êtes point garante des choses que vous contez, je puis, sans vous choquer, n'avoir pas la plus grande foi du monde en votre récit, quelque joliment qu'il soit fait' (LXXVI, 114).

There is perhaps a more important reason for the abbé's decision, namely, that fundamental ordering activity of consciousness we call narration. It is clearly Madame Du Noyer who has brought order to the abbé de Bucquoy's story, which I take to be essentially true even if he, himself, is very probably an imposter. ${ }^{17}$ It is clearly she who has made sense out of his world and structured his identity. It is clearly she who has succeded in narrating him to those around him, in presenting him in a specific way so as to obtain specific reactions. The abbé de Bucquoy becomes the hero of his escape from the Bastille only through Madame Du Noyer's retelling of his story. It is really thanks to her that this narration is born and comes alive.

\section{ALEX SOKALSKI}

Université de la Saskatchewan 


\section{Notes}

1 Three years after Madame Du Noyer's death, Antoine-Augustin Bruzen de la Martinière has Rabelais's shade say to her: 'Vous étiez une femme furieusement fertile en écritures'; 'IV. Entretien' in his Entretiens des ombres aux Champs Elisées, sur divers sujets d'histoire, de politique $\mathcal{E}$ de morale (Amsterdam: chez Henri Uytvverf, 1722), 444. In addition to various editions of the Lettres, the printed catalogue of the French Bibliothèque nationale lists under Du Noyer's name the religious text generally known by its short title Les Sentimens d'une âme penitente, first published at the end of the Seventeenth Century and regularly republished until well into the Nineteenth. In a note following the first entry the editors state that the text has also been attributed to dom [Louis] Pisant. Volume four of Barbier's Dictionnaire des ouvrages anonymes gives as source of the attribution to Du Noyer the 'Catalogue de Nantes'; (Paris, 1879; Hildesheim: Georg Olms Verlagsbuchhandlung, 1963), 468, d-f. There is a long note on the subject of this attribution in Arnelle (pseudonym of Mme de Clauzade) which basically recopies most of an exchange between readers in the Intermédiaire des chercheurs et des curieux from October through December 1877 but which the author note mistakenly dates from 1864; Les Filles de Madame Du Noyer, 1663-1720 (Paris: Fontemoing et Cie., [1921]), 311-13, n. 1.

2 The author of the 'Preface' to the contemporary English translation of the Lettres historiques rendered into that language as Letters From A Lady at Paris to A Lady at Avignon (London: W. Mears, 1716), writes: 'The Materials scattered up and down in these Letters furnished Sir Richard Steele with two Guardians upon the Life and Conduct of that famous Lady [i.e. Mme de Maintenon]. But we may say, without offence to that Gentleman, that the Stories are much more natural and agreable in the manner which this Lady [i.e. Mme Du Noyer] has related them, than in his Papers' ([7]).

3 Ron Browne, 'Humbugs and Waggeries', Factotum 22 (1986), 20-2. The anecdote from Madame Du Noyer, unidentified as to its origin, is to be found in the facsimile of page 82 of Baker's work reproduced on page 22 of the article.

4 'Sade s'est montré quelque peu ingrat à l'égard de Mme Du Noyer: alors qu'il l'a certainement beaucoup lue, si l'on s'en réfère à plusieurs notes du ms. 4010 de la Bibl. Nat....,' 'Document annexe du Livre V', Vie du marquis de Sade (Paris: Au Cercle du livre précieux, 1966), 268, n. 2. This volume of Lély's Vie is volume 2 of the CEuvres completes du marquis de Sade.

5 Histoire littéraire de Nîmes et de ses localités voisines, vol. 2 (Nîmes: chez Ballivet et Fabre, 1854), 51-3.

6 (Paris: Librairie José Corti, 1975), 41. The other text Brombert alludes to is Constantin de Renneville's L'Inquisition françoise ou l'Histoire de la Bastille, 4 vols. (Amsterdam: chez Balthazar Lakeman/Leide: chez Jean \& Herm. Verbeek, 1724).

7 Evenement des plus rares ou l'Histoire du Sr Abbé Comte de Buquoy singulierement son evasion du Fort-L'Eveque et de la Bastille... avec plusieurs de ses ouvrages vers et prose $\mathcal{E}$ particuliérement La Game des femmes (Bonnefoy: chez Jean de la Franchise Rüe de la Réforme à l'Espérance, 1719). The volume contains, in addition to the works mentioned in the title: 'L'Antimachiavelisme ou reflexions metaphisiques,' 'De la Moderation,' 'Specifique important ou sujet de consolation,' 'Reflexions sur le deces inopiné du Roi de Suede,' 'L'Encherissement des femmes,' ‘Preliminaires philosophiques a l'existence de Dieu ou Discours aux Atômes.' Gustave Brunet 
indicates that Bonnefoy is really Germany, Imprimeurs imaginaires et libraires supposés, Burt Franklin Research and Source Works Series 34 (New York: Burt Franklin, [1962]), 88-89.

8 This second title appears in a second edition as: A Un ami, Ec. ou Histoire de l'abbé de Buquoit (Paris: Chez Bailly, Libraire rue Saint-Honoré, Barrière des Sergens/Les Marchands de nouveautés, 1788).

9 Lettre LXXI of Lettres historiques et galantes, vol. 5 (Cologne: Pierre Marteau, 1712), 24. Future references to the Du Noyer text will be indicated in the body of the article with letter and page number.

10 Eduard Bodemann, ed., Aus den Briefen der Herzogin Elisabeth Charlotte von Orléans an die Kurfürstin Sophie von Hannover, vol. 2 (Hannover: Hahn'sche

Buchhandlung, 1891), letter 758, 275. Other references to this edition are indicated in the text by editor's name, followed by volume, letter and page number.

11 Eduard Bodemann, ed. Briefe der Herzogin Elisabeth Charlotte von Orléans an ihre frühere Hofmeisterin A. K. v. Harling, geb. v. Usseln, und deren Gemhal, Geh. Rath Fr. v. Harling zu Hannover (Hannover und Leipzig: Hahn'sche Buchhandlung, 1895), letter 40,104 . Future reference are indicated by editor's name, letter and page number.

12 Wilhelm Ludwig Holland, ed., Briefe der Herzogin Elisabeth Charlotte von Orléans aus den Jahren 1716 bis 1718 (Tübingen, H. Laupp, 1874), letter 794, 46. References in the text to this edition are by editor's name, letter and page number.

13 I offer here my own inadequate translations of the several citations from the 'princesse Palatine' in the order in which they appear in the text: 'I've heard nothing of the abbé Bucqo; I don't know him at all'; 'I have also asked about him, no one knows him. It must [not be true] that he was stuck in the Bastille. I cannot comprehend how one can escape from the Bastille'; 'he speaks so ill of our King, whom I loved so truly and still regret'; 'foolish abbé or Count de Bouquoy'; 'Fools never amuse me, I pity them so much, I don't find it funny when people harrass them'; 'where had this poor devil gathered together 14,000 florins? Once a fool, always a fool'; 'It is easy to believe that you have never wanted to associate much with fools; nothing good comes from fools'; 'I can't stand fools.'

14 François Ravaisson-Mollien, Archives de la Bastille d'après des documents inédits: Règne de Louis XIV (1702 à 1710), vol. 11 (Paris, 1866-1904), 336. Future references are given in the text by editor's name, volume and page number.

15 Frantz Funck-Brentano in his presentation on Latude in his Légendes et Archives de la Bastille (Paris: Hachette, 1904) also remarks on this latter's locquacity, especially in his writing ('Ces idées sont délayées dans un déluge de mots, une abondance de phrases inimaginables,' 192) and later quotes from the Duchesse d'Abrantès who describes her first encounter with the celebrated escapee. Her admiration of him, she writes, soon gave way to boredom because '[i]l ne parlait que de ses aventures avec une loquacité effrayante' (233). Latude, with Casanova and l'abbé de Bucquoy, form the century's most celebrated prison escapee trio.

16 This fact, the anonymous author most certainly found in volume two of de Renneville's Inquisition françoise, where one reads: 'Cette évasion de l'Abbé Comte de Bucquoit ne sera pas un des endroit le moins réjouissant de mon Histoire: elle a paru si prodigieuse, que lorsque j'arrivai en Hollande on la traitoit de fabuleuse. Le Roi même de la Grande Bretagne, Bienfaiteur admirable de ce Comte paroissoit en douter, lorsqu'il passa par la Haye pour venir prendre possession de 
ses Couronnes: mais le détail que j'en fis à S.M. \& les marques qu'il vit sur mon visage des cruautez de Bernaville, qui me plongea dans une basse-fosse, pour me punir d'une évasion dont j'étois innocent, lui confirmérent parfaitement cette verité' (91).

17 This appears to be the conclusion of $\mathrm{D}^{\prime}$ Argenson in his letter of 1 March 1710 to Pontchartrain (Ravaisson, Archives, 11: 348-9). Latude, who knew of what he spoke, appears to agree that Bucquoy was a 'hoaxer'. See Christopher Sharp, trans., Escape from the Bastille: The Life and Legend of Latude, by Claude Quétel (Cambridge, UK: Polity Press, 1990), 47. 